ORIGINAL ARTICLE / ARTIGO ORIGINAL

\title{
Sexual, reproductive health and health status of female sex workers in 12 Brazilian cities, 2016
}

\author{
Saude sexual, reprodutiva e estado de saúde de mulheres trabalhadoras do \\ sexo em 12 cidades brasileiras, 2016
}

\author{
Letícia Penna Bragal (D), Giseli Nogueira Damacena" (D), Célia Landmann Szwarcwald" (D), \\ Mark Drew Crosland Guimarães"II
}

\begin{abstract}
Objective: To investigate differences in sexual, reproductive health and health status indicators of female sex workers in 12 Brazilian cities. Methods: Cross-sectional study of biological and behavioral surveillance survey with a minimum sample of 350 female sex workers per city, recruited by respondent driven sampling, in 2016. Complex sample design was considered in the data analysis. Indicators and $95 \%$ confidence intervals related to sexual and reproductive health, and health status were described separately by city and for the total sample. Results: The total sample consisted of 4,328 female sex workers. The coverage of Pap smear exam, human immunodeficiency virus and syphilis tests and antenatal care indicators varied by 20 percentages points or more. Pap smear exam coverage ranged from $53.4 \%$ in Recife to $73.0 \%$ in Porto Alegre. The highest percentage of female sex workers who had never been tested for human immunodeficiency virus and syphilis was in Fortaleza (36.8 and 63.8\%, respectively). Antenatal coverage ranged from $61.1 \%$ in Salvador to $99.0 \%$ in Curitiba. In five cities, the proportion of female sex workers who disclosed their sex work status in health services was over $20.0 \%$. Conclusion: The differences between the indicators in the 12 cities followed the Brazilian population profile, with more vulnerable sex workers in the North and Northeast regions. The results show that it is essential to consider the barriers to accessing health, such as stigma and discrimination, which restrict the addressing of female sex workers specific needs.
\end{abstract}

Keywords: sexual and reproductive health. health status disparities. sex workers. social discrimination. vulnerable populations. health surveys.

\footnotetext{
'Post-graduate program in Public Health Epidemiology, Escola Nacional de Saúde Pública Sergio Arouca, Fundação Oswaldo Cruz - Rio de Janeiro (RJ), Brazil.

"Laboratório de Informações em Saúde, Instituto de Comunicação e Informação Científica e Tecnológica em Saúde, Fundação Oswaldo Cruz - Rio de Janeiro (RJ), Brazil.

I'Department of Preventive and Social Medicine, Faculdade de Medicina, Universidade Federal de Minas Gerais - Minas Gerais (MG), Brazil.

Corresponding author: Letícia Penna Braga. Avenida Brasil, 4365, Biblioteca de Manguinhos, sala 225, Manguinhos, CEP: 21040-360, Rio de Janeiro (RJ), Brasil. E-mail: leticiapbraga@gmail.com

Conflict of interests: nothing to declare - Financial support: Financial support for the Biological and Behavioral Surveillance Survey, 2016 was provided by the Brazilian Ministry of Health, through the Health Surveillance Secretariat, Department of Chronic Conditions and Sexually Transmitted Diseases (Departamento de Condições Crônicas e Infecções Sexualmente Transmissíveis - DCCI) Financing Code LN7901-BR. Letícia Penna Braga received a Full Doctorate scholarship from Coordenação de Aperfeiçoamento de Pessoal de Nivel Superior (Capes): Financing Code 001.
} 
RESUMO: Objetivo: Investigar diferenças nos indicadores de saúde sexual, reprodutiva e de estado de saúde de mulheres trabalhadoras do sexo em 12 cidades brasileiras. Métodos: Estudo de corte transversal comportamental e biológico, com amostra mínima de 350 mulheres trabalhadoras do sexo por cidade, recrutadas por Respondent-Driven Samplig, em 2016. Na análise de dados, foi considerado o desenho complexo de amostragem. Foram apresentados indicadores e respectivos intervalos de $95 \%$ de confiança relacionados à saúde sexual, reprodutiva e ao estado de saúde separadamente por cidade e para a amostra total. Resultados: A amostra total foi de 4.328 mulheres trabalhadoras do sexo. A cobertura de exame de Papanicolau e teste para vírus da imunodeficiência humana e sífilis, e os indicadores de pré-natal apresentaram variação igual ou superior a 20 pontos percentuais. A cobertura de exame de Papanicolau variou de 53,4\%, em Recife, a 73\%, em Porto Alegre. O maior percentual de mulheres trabalhadoras do sexo que nunca realizaram o teste para vírus da imunodeficiência humana e sífilis foi registrado em Fortaleza (36,8 e 63,8\%, respectivamente). A cobertura de pré-natal variou de $61,1 \%$, em Salvador, a $99 \%$, em Curitiba. Em cinco cidades, o percentual de participantes que afirmou já ter sentido discriminação no serviço de saúde por ser trabalhadora do sexo foi superior a $20 \%$. Conclusões: As diferenças entre os indicadores nas 12 cidades acompanharam o perfil da população brasileira, com mulheres trabalhadoras do sexo mais vulneráveis nas regiões Norte e Nordeste. Os resultados mostram que é fundamental considerar as barreiras de acesso à saúde, como o estigma e a discriminação, que impedem a contemplação das necessidades específicas dessas mulheres.

Palavras-chave: saúde sexual e reprodutiva. desigualdades em saúde. profissionais do sexo. discriminação social. populações vulneráveis. inquéritos de saúde.

\section{INTRODUCTION}

Since the beginning of the epidemic of acquired immunodeficiency syndrome (AIDS), female sex workers (FSW) have been recognized as a key population due to the high risk of infection with the human immunodeficiency virus (HIV) $)^{1}$. In addition to the multiplicity of partners and unprotected sexual intercourse, structural characteristics that include precarious socioeconomic conditions, low education, and violence are factors known to be associated with adverse health outcomes ${ }^{2}$ and reflect the greater vulnerability of FSW to HIV infection and other sexually transmitted infections (STI),

It is estimated that in Brazil, FSW represent $1.2 \%$ of the female population aged 15 to 49, which corresponds to approximately half a million women ${ }^{5}$. Previous studies carried out in Brazil, in this population group, show an HIV prevalence 10-15 times higher than that found in the general population of women ${ }^{6}$.

The concept of sexual and reproductive health includes maternal and perinatal health, family planning and contraception, fertility, prevention of STI and cervical cancer, access to safe abortion, and the end of violence against women ${ }^{7,8}$. Many advances have taken place in the field of women's health with the inclusion of gender, race, and class perspectives ${ }^{9}$, but little focus is given to the health of FSW in view of the stigma and discrimination related to the profession, important barriers in accessing health services ${ }^{10}$. 
Under the hypothesis that sexual and reproductive health and health status indicators in FSW are different from those of women in the Brazilian population, the aim of this study was to investigate the differences in sexual and reproductive health and health status indicators in FSW from 12 Brazilian cities.

\section{METHODS}

The data analyzed in this article were collected in the "National Study of Behaviors, Attitudes, Practices, and Prevalence of HIV, Syphilis, and Hepatitis B and C among Female Sex Workers Health Chain Project II" (Estudo de abrangência nacional de comportamentos, atitudes, práticas e prevalência de HIV, sifilis e hepatites B e C entre mulheres trabalhadoras do sexoProjeto Corrente da Saúde II). This is a biological and behavioral cross-sectional study carried out between July and November 2016, with 4,328 FSW recruited by Respondent-Driven Sampling (RDS) in 12 Brazilian cities. The project was approved by the Ethics Committee of Fundação Oswaldo Cruz (Protocol No. 1.338.989). All participants signed the Informed Consent and the data confidentiality terms.

Participating cities were selected by the Department of Chronic Conditions and Sexually Transmitted Diseases of the Ministry of Health (Departamento de Condições Crônicas e Infecções Sexualmente Transmissíveis do Ministério da Saúde - DCCI/MS), according to geographic location and epidemiological relevance of HIV/AIDS in Brazil, distributed into five regions:

a) North: Manaus and Belém;

b) Northeast: Fortaleza, Recife, and Salvador;

c) Southeast: Belo Horizonte, Rio de Janeiro, and São Paulo;

d) South: Curitiba and Porto Alegre;

e) Midwest: Campo Grande and Brasília.

The sample was pre-established by the DCCI in at least 350 participants in each city.

Women aged 18 years old or older, who worked as sex worker in one of the selected cities and who had at least one sexual intercourse in exchange for money in the four months prior to the survey, were eligible to participate in the study. Participants had to present a valid coupon and could not have participated in the edition of this survey.

In each city, before the beginning of data collection, a formative research was carried out in order to establish the best way to implement the study and to recruit five to ten sex workers, in a non-random way, which were named "seeds". Seeds with varied characteristics (age, race/color, education, workplace) were chosen in order to obtain more diversity in the sample. Each seed received three coupons to invite other FSW from their social network to participate in the study. Participants recruited by the seed, in turn, received three invitations to recruit FSW from their social network, and so on, until a sample of 350 participants in each city was reached. 
Each participant received primary incentive for participating in the study: gift (bag containing personal care products, condoms, and lubricant), snacks, and reimbursement for transportation. The secondary incentive consisted of paying $\mathrm{R} \$ 30$ for each person recruited by the participant and who participated in the study.

Participants answered a socio-behavioral questionnaire that involved the following aspects:

a) sociodemographic characteristics;

b) knowledge about sexually transmitted infections (STI) and AIDS;

c) social support and access to educational and preventive material;

d) HIV, syphilis, and hepatitis B and C testing;

e) health status, health care, and STI;

f) violence;

g) sexual behavior with regular partners and clients; and

h) use of alcohol and drugs.

Rapid tests for HIV, syphilis, and hepatitis B and C were performed, in accordance with the guidelines recommended by the Ministry of Health ${ }^{11}$. Details on the implementation of Projeto Corrente da Saúde II were described by Damacena et al. ${ }^{12}$.

\section{VARIABLES}

The variables analyzed in this article refer to indicators of sexual, reproductive, and self-rated health status. For contextualization, the variables described were education (categorized as did not study/incomplete elementary school, complete elementary school/incomplete middle school, complete middle school/incomplete high school and complete high school or more); work in street points, through the question "Where is your main workplace as a sex worker?"; and age at onset of sex work (categorized into $<18$ and $\geq 18$ years of age). More details regarding these variables were described in a previous publication ${ }^{13}$.

Sexual and reproductive health indicators were:

a) Pap smear within the three years preceding the research, based on the Brazilian Guidelines for screening for cervical cancer ${ }^{14}$;

b) HIV and syphilis tests: proportion of FSW who were tested for HIV and syphilis in the 12 months preceding the survey and between 12 months and more; and proportion of those never tested for HIV and syphilis. Among the FSW who have never been tested for HIV, their main reasons were analyzed. Of those who had been tested for HIV at some point in their lives, the proportion of those who had been tested in a public health service was calculated;

c) condom use every time in vaginal and anal sex with steady partners and clients in the six months prior to the survey. 
HIV and syphilis testing indicators related to condom use were developed based on the World Health Organization (WHO) guidelines on HIV prevention, diagnosis, and care for key populations ${ }^{15}$;

d) contraception: proportion of women who use any contraceptive method (among those who did not have tubal sterilization) and type of contraceptive method used; and

e) antenatal care: antenatal coverage, proportion of women who started antenatal care in the first trimester of pregnancy and those who had seven or more antenatal consultations among women who gave birth up to two years before the research.

These indicators were defined based on the Ministry of Health's low-risk antenatal care recommendations ${ }^{16}$. The indicators related to health status were:

f) self-rated health, obtained through the question: "In general, how do you rate your health?", categorized as "very good/good", "regular", and "bad/very bad";

g) proportion of FSW with positive score for major depressive disorder episodes.

This indicator was defined considering the Patient Health Questionnaire-2 (PHQ-2) scale, which aims to screen for depressive disorders through two questions referring to the last two weeks: "How many days did you have little interest or little pleasure in performing usual activities?" and "How often have you felt depressed, down or hopeless?". Each answer is given a score ( 0 : not at all, +1 : several days, +2 : more than half of the days, +3 : nearly every day). The answers to the two questions are added together and a score greater than or equal to 3 means that major depressive disorders is likely and further evaluation is required by a qualified professional for the diagnosis of depressive disorders ${ }^{17}$;

h) proportion of FSW who use the Unified Health System (Sistema Único de Saúde - SUS) as their usual source of care, based on the question: "What place do you usually go to when you need health care?"; and

i) discrimination in health services: proportion of FSW who felt discriminated in health services because they were sex workers, to those who answered "because I am a sex worker" to the following question: "Have you ever felt discriminated against or treated worse than other people in the health service, by a doctor or other health professional for one of these reasons?"; and proportion of FSW who always declare themselves as sex workers when they attend the health service.

\section{DATA ANALYSIS}

All indicators were presented with their respective $95 \%$ confidence intervals $(95 \% \mathrm{CI})$, separately by city and for the total sample. The $\chi^{2}$ test of homogeneity of the distributions of the variables, with a significance level of $5 \%$, was used to analyze differences in health indicators between the FSW of the participating cities. 
The statistical analysis of the data took into account the complex recruitment sampling design by RDS, considering the dependence of observations and the different selection probabilities $^{18}$.

The size of each participant's network was obtained by the question: "How many sex workers who work here in the city do you know personally, that is, do you know them and do they know you?".

The sample was weighted by the inverse of the network size of each participant ${ }^{12}$, and the seeds were excluded from the analysis, as recommended by Salganik, 2004 ${ }^{19}$. The SPSS 21.0 software was used for the analyses.

\section{RESULTS}

The total sample consisted of 4,328 FSW. A profile of more vulnerable women was found in the North (Manaus and Belém) and Northeast (Fortaleza, Recife, and Salvador) regions, with very low education, reaching $32.7 \%$ with incomplete elementary education, in Salvador; predominance of work in street points (higher in Recife, 84.4\%; lower in Belo Horizonte, 7.4\%); and higher proportions of beginning sex work before the age of 18 (higher in Recife, $62.6 \%$; lower in Belo Horizonte, $11.3 \%$ ).

Significant differences were found in the distribution of all health indicators calculated by city. The variation in the coverage of Pap smears in the last three years was almost 20 percentage points, being lower in Recife (53.4\%) and higher in Porto Alegre (73\%). The proportion of FSW who underwent an HIV test in the year preceding the survey ranged from $24.9 \%$ in Salvador to $61 \%$ in Porto Alegre. In the case of syphilis testing in the last year, the variation between cities was greater, from $9.6 \%$ in Fortaleza to $43.5 \%$ in Porto Alegre and Campo Grande. With regard to FSW who had never been tested for HIV and syphilis, the lowest percentages were found in Belo Horizonte, $10 \%$ for HIV and $28.4 \%$ for syphilis, and the highest in Fortaleza, $36.8 \%$ for HIV and $63.8 \%$ for syphilis (Table 1).

The main reasons given for never having been tested for HIV were "not feeling at risk" (ranging from 23.4 to $62.8 \%$ among municipalities) and "being afraid or ashamed" (ranging from 13.7 to $53.5 \%$ among municipalities). The city of Campo Grande had the lowest percentage of HIV tests performed in the public service (55.5\%), while Fortaleza had the highest percentage (87.3\%) (Table 2$)$.

The percentage of condom use with a steady partner every time during vaginal sex was above $40 \%$ in five cities: Manaus, Fortaleza, Recife, Porto Alegre, and Brasília. In the case of clients, this indicator ranged from $67.3 \%$, in Fortaleza, to $96 \%$, in Campo Grande. As for the use of condoms with a steady partner in anal sex, the percentage ranged from $24 \%$, in São Paulo, to $53.4 \%$, in Recife. For clients, this variation ranged from $67.5 \%$ in Salvador to 95.9\% in Campo Grande (Table 3).

As for contraception, Salvador had the highest percentage of women using any contraceptive method $(83.8 \%)$, with $45.6 \%$ of FSW opting for male condoms, while Manaus 
Table 1. Proportional distribution and confidence intervals $(95 \% \mathrm{Cl})$ of indicators for Pap smears, HIV and syphilis testing of female sex workers, according to the study city. Brazil, 2016.

\begin{tabular}{|c|c|c|c|c|c|c|c|}
\hline \multirow{3}{*}{ City } & \multirow{2}{*}{$\begin{array}{c}\text { Pap } \\
\text { smear } \\
\text { within } \\
\text { the last } 3 \\
\text { years }\end{array}$} & \multicolumn{3}{|c|}{ HIV testing } & \multicolumn{3}{|c|}{ Syphilis testing } \\
\hline & & $\begin{array}{l}\text { HIV testing } \\
<12 \text { months }\end{array}$ & $\begin{array}{c}\text { HIV } \\
\text { testing } \\
12+\text { months }\end{array}$ & $\begin{array}{l}\text { Never } \\
\text { tested for } \\
\text { HIV }\end{array}$ & $\begin{array}{c}\text { Syphilis } \\
\text { testing } \\
<12 \\
\text { months }\end{array}$ & $\begin{array}{c}\text { Syphilis } \\
\text { testing } \\
12+\text { months }\end{array}$ & $\begin{array}{l}\text { Never } \\
\text { tested for } \\
\text { Syphilis }\end{array}$ \\
\hline & $\%(95 \% \mathrm{Cl})$ & $\%(95 \% \mathrm{Cl})$ & $\%(95 \% \mathrm{Cl})$ & $\%(95 \% \mathrm{Cl})$ & $\%(95 \% \mathrm{Cl})$ & $\%(95 \% \mathrm{Cl})$ & $\%(95 \% \mathrm{Cl})$ \\
\hline Manaus & $\begin{array}{c}66.6 \\
(61.0-71.7)\end{array}$ & $\begin{array}{c}39.7 \\
(33.8-45.9)\end{array}$ & $\begin{array}{c}34.6 \\
(29.4-40.2)\end{array}$ & $\begin{array}{c}24.4 \\
(19.8-29.7)\end{array}$ & $\begin{array}{c}19.3 \\
(15.4-24.0)\end{array}$ & $\begin{array}{c}21.2 \\
(16.6-26.6)\end{array}$ & $\begin{array}{c}58.1 \\
(52.4-63.7)\end{array}$ \\
\hline Belém & $\begin{array}{c}61.8 \\
(55.4-67.9)\end{array}$ & $\begin{array}{c}27.1 \\
(21.6-33.4)\end{array}$ & $\begin{array}{c}35.1 \\
(29.2-41.5)\end{array}$ & $\begin{array}{c}32.2 \\
(30.9-43.9)\end{array}$ & $\begin{array}{c}11.4 \\
(8.2-15.8)\end{array}$ & $\begin{array}{c}24.8 \\
(19.3-31.3)\end{array}$ & $\begin{array}{c}63.0 \\
(56.7-68.9)\end{array}$ \\
\hline Fortaleza & $\begin{array}{c}55.7 \\
(48.0-63.1)\end{array}$ & $\begin{array}{c}16.8 \\
(12.7-21.9)\end{array}$ & $\begin{array}{c}45.9 \\
(38.4-53.6)\end{array}$ & $\begin{array}{c}36.8 \\
(29.9-44.3)\end{array}$ & $\begin{array}{c}9.6 \\
(6.5-14.1)\end{array}$ & $\begin{array}{c}26.0 \\
(20.4-32.5)\end{array}$ & $\begin{array}{c}63.8 \\
(57.2-69.9)\end{array}$ \\
\hline Recife & $\begin{array}{c}53.4 \\
(46.4-60.2)\end{array}$ & $\begin{array}{c}28.7 \\
(22.8-35.4)\end{array}$ & $\begin{array}{c}43.6 \\
(36.7-50.8)\end{array}$ & $\begin{array}{c}26.1 \\
(20.8-32.3)\end{array}$ & $\begin{array}{c}18.8 \\
(14.2-24.3)\end{array}$ & $\begin{array}{c}27.9 \\
(22.2-34.3)\end{array}$ & $\begin{array}{c}50.8 \\
(43.9-57.7)\end{array}$ \\
\hline Salvador & $\begin{array}{c}54.7 \\
(47.9-61.3)\end{array}$ & $\begin{array}{c}24.9 \\
(19.8-30.7)\end{array}$ & $\begin{array}{c}49.3 \\
(43.1-55.5)\end{array}$ & $\begin{array}{c}25.8 \\
(20.8-31.6)\end{array}$ & $\begin{array}{c}22.5 \\
(17.1-28.8)\end{array}$ & $\begin{array}{c}27.3 \\
(21.5-34.0)\end{array}$ & $\begin{array}{c}50.2 \\
(43.6-56.8)\end{array}$ \\
\hline $\begin{array}{l}\text { Belo } \\
\text { Horizonte }\end{array}$ & $\begin{array}{c}70.1 \\
(62.0-77.1)\end{array}$ & $\begin{array}{c}46.9 \\
(39.2-54.7)\end{array}$ & $\begin{array}{c}42.9 \\
(35.7-50.4)\end{array}$ & $\begin{array}{c}10.0 \\
(6.3-15.4)\end{array}$ & $\begin{array}{c}28.4 \\
(22.0-35.7)\end{array}$ & $\begin{array}{c}39.8 \\
(32.3-47.8)\end{array}$ & $\begin{array}{c}28.4 \\
(21.7-36.2)\end{array}$ \\
\hline $\begin{array}{l}\text { City of Rio } \\
\text { de Janeiro }\end{array}$ & $\begin{array}{c}60.1 \\
(53.9-66.1)\end{array}$ & $\begin{array}{c}44.2 \\
(37.5-51.0)\end{array}$ & $\begin{array}{c}39.3 \\
(33.0-46.1)\end{array}$ & $\begin{array}{c}15.3 \\
(11.0-20.8)\end{array}$ & $\begin{array}{c}30.5 \\
(24.5-37.2)\end{array}$ & $\begin{array}{c}24.7 \\
(19.6-30.6)\end{array}$ & $\begin{array}{c}41.2 \\
(34.8-47.9)\end{array}$ \\
\hline $\begin{array}{l}\text { City of } \\
\text { São Paulo }\end{array}$ & $\begin{array}{c}63.3 \\
(55.8-70.2)\end{array}$ & $\begin{array}{c}45.5 \\
(38.8-52.4)\end{array}$ & $\begin{array}{c}37.3 \\
(30.4-44.7)\end{array}$ & $\begin{array}{c}16.7 \\
(11.8-23.1)\end{array}$ & $\begin{array}{c}27.8 \\
(22.0-34.6)\end{array}$ & $\begin{array}{c}33.4 \\
(27.0-40.5)\end{array}$ & $\begin{array}{c}38.6 \\
(31.6-46.0)\end{array}$ \\
\hline Curitiba & $\begin{array}{c}64.2 \\
(57.1-70.8)\end{array}$ & $\begin{array}{c}47.0 \\
(39.5-54.6)\end{array}$ & $\begin{array}{c}32.6 \\
(26.2-39.8)\end{array}$ & $\begin{array}{c}18.2 \\
(13.1-24.6)\end{array}$ & $\begin{array}{c}21.4 \\
(16.3-27.6)\end{array}$ & $\begin{array}{c}17.1 \\
(12.6-22.7)\end{array}$ & $\begin{array}{c}56.2 \\
(49.2-62.9)\end{array}$ \\
\hline $\begin{array}{l}\text { Porto } \\
\text { Alegre }\end{array}$ & $\begin{array}{c}73.0 \\
(66.0-79.0)\end{array}$ & $\begin{array}{c}61.0 \\
(53.5-68.0)\end{array}$ & $\begin{array}{c}27.5 \\
(21.7-34.2)\end{array}$ & $\begin{array}{c}10.4 \\
(6.3-16.8)\end{array}$ & $\begin{array}{c}43.5 \\
(36.8-50.4)\end{array}$ & $\begin{array}{c}18.7 \\
(14.1-24.3)\end{array}$ & $\begin{array}{c}35.1 \\
(28.6-42.3)\end{array}$ \\
\hline $\begin{array}{l}\text { Campo } \\
\text { Grande }\end{array}$ & $\begin{array}{c}68.2 \\
(62.0-73.8)\end{array}$ & $\begin{array}{c}58.7 \\
(52.2-64.9)\end{array}$ & $\begin{array}{c}22.4 \\
(17.6-28.0)\end{array}$ & $\begin{array}{c}18.9 \\
(14.1-24.8)\end{array}$ & $\begin{array}{c}43.5 \\
(37.6-49.6)\end{array}$ & $\begin{array}{c}19.6 \\
(15.2-25.0)\end{array}$ & $\begin{array}{c}36.2 \\
(29.8-43.1)\end{array}$ \\
\hline Brasília & $\begin{array}{c}57.8 \\
(51.2-64.1)\end{array}$ & $\begin{array}{c}26.4 \\
(21.3-32.2)\end{array}$ & $\begin{array}{c}42.1 \\
(35.9-48.6)\end{array}$ & $\begin{array}{c}32.0 \\
(26.0-38.8)\end{array}$ & $\begin{array}{c}15.9 \\
(12.0-20.8)\end{array}$ & $\begin{array}{c}32.4 \\
(26.4-39.1)\end{array}$ & $\begin{array}{c}51.0 \\
(43.9-58.1)\end{array}$ \\
\hline Total & $\begin{array}{c}62.3 \\
(60.4-64.3)\end{array}$ & $\begin{array}{c}38.9 \\
(37.0-40.9)\end{array}$ & $\begin{array}{c}37.8 \\
(35.9-39.7)\end{array}$ & $\begin{array}{c}22.5 \\
(20.9-24.2)\end{array}$ & $\begin{array}{c}24.5 \\
(22.9-26.2)\end{array}$ & $\begin{array}{c}26.1 \\
(24.4-27.8)\end{array}$ & $\begin{array}{c}47.6 \\
(45.6-49.6)\end{array}$ \\
\hline$p$-value $\chi^{2}$ & $<0.001$ & & $<0.001$ & & & $<0.001$ & \\
\hline
\end{tabular}

recorded the lowest percentage (55.1\%), also being the male condom the most used method (53.4\%). The oral pill was the most used contraceptive method in Curitiba (31.2\%), Porto Alegre (35.9\%), Belo Horizonte (42.7\%), and Campo Grande (52.8\%). Belém was the only city in which injectable contraceptives were the most used method (48.8\%). 
Table 2. Proportional distribution and confidence intervals $(95 \% \mathrm{Cl})$ of reasons for never having been tested for HIV and last tested for HIV in the public health service for female sex workers, according to the study city. Brazil, 2016.

\begin{tabular}{|c|c|c|c|c|}
\hline \multirow{3}{*}{ City } & \multicolumn{3}{|c|}{ Reason for never having been tested for HIV } & \multirow{2}{*}{$\begin{array}{l}\text { HIV testing - } \\
\text { public services }\end{array}$} \\
\hline & $\begin{array}{l}\text { Not considering } \\
\text { oneself at risk }\end{array}$ & $\begin{array}{l}\text { Not knowing the } \\
\text { testing locations }\end{array}$ & Afraid /ashamed & \\
\hline & $\%(95 \% \mathrm{Cl})$ & $\%(95 \% \mathrm{Cl})$ & $\%(95 \% \mathrm{Cl})$ & $\%(95 \% \mathrm{Cl})$ \\
\hline Manaus & $62.8(51.4-72.9)$ & $3.8(1.2-11.4)$ & $13.7(7.4-24.0)$ & $69.2(61.8-75.7)$ \\
\hline Belém & $22.9(15.7-32.3)$ & $8.5(3.6-18.8)$ & $38.9(29.1-49.8)$ & $69.8(61.7-76.8)$ \\
\hline Fortaleza & $28.2(18.0-41.3)$ & $8.5(3.0-22.1)$ & $41.2(28.3-44.4)$ & $87.3(81.4-91.6)$ \\
\hline Recife & $56.0(41.9-69.1)$ & $4.5(1.3-14.5)$ & $25.0(14.9-39.0)$ & $84.6(78.0-89.6)$ \\
\hline Salvador & $49.1(35.8-62.6)$ & $15.0(7.6-27.4)$ & $35.9(24.3-49.5)$ & $76.9(70.0-82.7)$ \\
\hline Belo Horizonte & $53.3(32.9-72.7)$ & $10.2(2.7-31.2)$ & $23.5(11.8-41.3)$ & $71.3(63.7-77.9)$ \\
\hline Rio de Janeiro & $28.0(15.5-45.3)$ & $23.3(11.1-42.6)$ & $40.5(24.8-58.5)$ & $77.4(70.7-82.9)$ \\
\hline São Paulo & $57.9(40.0-74.0)$ & $2.1(0.3-13.8)$ & $21.4(10.6-38.4)$ & $82.2(75.4-87.5)$ \\
\hline Curitiba & $23.4(10.5-44.1)$ & 7.9 (2.9-19.8) & $53.5(34.3-71.7)$ & $61.8(53.5-69.4)$ \\
\hline Porto Alegre & $26.2(8.6-57.4)$ & $17.5(4.7-47.5)$ & $42.8(20.6-68.3)$ & 79.5 (73.2-84.7) \\
\hline Campo Grande & $48.6(33.6-63.8)$ & $1.9(0.3-11.7)$ & $19.3(9.8-34.5)$ & $55.5(48.3-62.5)$ \\
\hline Brasília & $38.6(27.8-50.7)$ & $5.9(2.3-14.6)$ & $44.0(32.7-55.9)$ & $80.0(76.2-88.1)$ \\
\hline Total & $40.4(36.2-44.7)$ & $8.5(6.3-11.4)$ & $34.0(30.0-38.2)$ & $74.7(72.8-76.6)$ \\
\hline p-value $\chi^{2}$ & & $<0.001$ & & $<0.001$ \\
\hline
\end{tabular}

Antenatal coverage was over $90 \%$ in one third of the cities (São Paulo, Curitiba, Porto Alegre, and Campo Grande), ranging from $61.1 \%$ in Salvador to $99 \%$ in Curitiba. Porto Alegre was the only city with a percentage greater than $80 \%$ of antenatal care in the first trimester of pregnancy. Belo Horizonte had the highest proportion of FSW who attended seven or more antenatal consultations $(83.9 \%)$, while Salvador had the lowest proportion (28\%) (Table 4).

As for health status indicators, Porto Alegre had the highest percentage of women who rated their health as very good/good $(77.7 \%)$, while Salvador had the lowest percentage $(50.6 \%)$ and the highest percentage of self-assessment of health as bad/very bad $(8.7 \%)$. In the cities of Recife, Rio de Janeiro, São Paulo, Campo Grande, and Brasília, more than 
Table 3. Proportional distribution and confidence intervals $(95 \% \mathrm{Cl})$ of indicators of condom use in vaginal and anal sex among female sex workers according to the study city. Brazil, 2016.

\begin{tabular}{|c|c|c|c|}
\hline \multirow{3}{*}{ City } & \multicolumn{2}{|c|}{ Condom in vaginal sex* } & \multirow{2}{*}{$\begin{array}{c}\text { Condom in anal sex** } \\
\text { Steady partner }\end{array}$} \\
\hline & Steady partner & Clients & \\
\hline & $\%(95 \% \mathrm{Cl})$ & $\%(95 \% \mathrm{Cl})$ & $\%(95 \% \mathrm{Cl})$ \\
\hline Manaus & $41.3(33.5-49.5)$ & $91.4(87.4-94.2)$ & $51.3(39.9-62.5)$ \\
\hline Belém & $28.3(18.9-40.0)$ & $71.2(65.0-76.7)$ & $40.2(27.0-55.0)$ \\
\hline Fortaleza & $49.5(39.5-59.5)$ & $67.3(60.0-73.9)$ & $45.5(32.2-59.5)$ \\
\hline Recife & 43.5 (33.9-53.7) & 86.7 (81.7-90.5) & $53.4(41.6-64.8)$ \\
\hline Salvador & $25.0(17.3-34.7)$ & $72.1(65.2-78.2)$ & $31.4(22.4-42.2)$ \\
\hline Belo Horizonte & $28.0(19.1-39.1)$ & $91.6(85.9-95.1)$ & $34.7(21.8-50.3)$ \\
\hline Rio de Janeiro & $30.1(23.7-37.3)$ & $79.2(73.1-84.2)$ & $24.2(17.6-32.3)$ \\
\hline São Paulo & $23.3(16.3-32.1)$ & $81.3(74.5-86.5)$ & $24.0(13.2-39.6)$ \\
\hline Curitiba & $37.7(29.7-46.3)$ & $74.0(66.1-80.7)$ & $44.0(32.7-56.0)$ \\
\hline Porto Alegre & $46.2(36.9-55.7)$ & $71.8(65.0-77.7)$ & $51.2(40.5-61.8)$ \\
\hline Campo Grande & $26.4(20.2-33.8)$ & $96.0(93.0-97.7)$ & $26.7(19.1-36.1)$ \\
\hline Brasília & $41.4(34.3-48.9)$ & $82.8(76.8-87.5)$ & $51.1(41.5-60.5)$ \\
\hline Total & $34.8(32.3-37.4)$ & $80.5(78.8-82.1)$ & $38.9(35.6-42.3)$ \\
\hline$p$-value $\chi^{2}$ & $<0.001$ & $<0.001$ & $<0.001$ \\
\hline
\end{tabular}

$30 \%$ of the participants had a positive score for major depressive episodes on the PHQ-2 scale. This percentage ranged from $11 \%$, in Manaus, to $46.6 \%$, in Campo Grande.

Altogether, $90.2 \%$ of FSW use the SUS as their usual source of care. This percentage was above $90 \%$ in Manaus, Belém, Recife, Rio de Janeiro, São Paulo, Curitiba, and Porto Alegre. The lowest rate was registered in Belo Horizonte (76.2\%) and the highest, in Recife (97.8\%). Approximately one fifth of the participants stated that they had already felt discriminated against in the health service for being a sex worker. The municipalities of Fortaleza, Belo Horizonte, and Porto Alegre had the highest percentages (29.6, 28.3, and 27\%, respectively). Recife had the highest percentage of FSW who revealed to be sex workers when they in a health service (42.5\%), while the lowest occurred in Brasilia (11.9\%) (Table 5). 
Table 4. Proportional distribution and confidence intervals $(95 \% \mathrm{Cl})$ of contraceptive indicators and antenatal coverage in female sex workers, according to the study city. Brazil, 2016.

\begin{tabular}{|c|c|c|c|c|c|c|c|}
\hline \multirow{3}{*}{ City } & \multirow{2}{*}{$\begin{array}{c}\text { Contraceptive } \\
\text { use }\end{array}$} & \multicolumn{3}{|c|}{ Type of contraceptive used } & \multirow{2}{*}{$\begin{array}{l}\text { Prenatal } \\
\text { coverage }\end{array}$} & \multirow{2}{*}{$\begin{array}{l}\text { Start of } \\
\text { prenatal } \\
\text { care in } \\
\text { the } 1^{\text {st }} \\
\text { trimester }\end{array}$} & \multirow{2}{*}{$\begin{array}{l}\text { 7+ prenatal } \\
\text { consultations }\end{array}$} \\
\hline & & Oral pill & $\begin{array}{c}\text { Male } \\
\text { condom }\end{array}$ & $\begin{array}{c}\text { Injectable } \\
\text { contraceptive }\end{array}$ & & & \\
\hline & $\%(95 \% \mathrm{Cl})$ & $\%(95 \% \mathrm{Cl})$ & $\%(95 \% \mathrm{Cl})$ & $\%(95 \% \mathrm{Cl})$ & $\%(95 \% \mathrm{Cl})$ & $\%(95 \% \mathrm{Cl})$ & $\%(95 \% \mathrm{Cl})$ \\
\hline Manaus & $\begin{array}{c}55.1 \\
(48.6-61.4)\end{array}$ & $\begin{array}{c}11.1 \\
(7.0-17.1)\end{array}$ & $\begin{array}{c}83.7 \\
(70.1-91.8)\end{array}$ & $\begin{array}{c}33.8 \\
(26.4-42.2)\end{array}$ & $\begin{array}{c}83.7 \\
(70.1-91.8)\end{array}$ & $\begin{array}{c}53.7 \\
(38.9-67.8)\end{array}$ & $\begin{array}{c}53.8 \\
(36.3-70.4)\end{array}$ \\
\hline Belém & $\begin{array}{c}50.8 \\
(43.5-58.1)\end{array}$ & $\begin{array}{c}13.2 \\
(8.5-19.9)\end{array}$ & $\begin{array}{c}80.0 \\
(63.7-90.1)\end{array}$ & $\begin{array}{c}48.8 \\
(38.2-59.5)\end{array}$ & $\begin{array}{c}80.0 \\
(63.7-90.1)\end{array}$ & $\begin{array}{c}64.2 \\
(46.9-78.5)\end{array}$ & $\begin{array}{c}72.6 \\
(54.2-85.6)\end{array}$ \\
\hline Fortaleza & $\begin{array}{c}63.8 \\
(57.0-70.1)\end{array}$ & $\begin{array}{c}26.5 \\
(19.4-35.2)\end{array}$ & $\begin{array}{c}88.5 \\
(73.5-95.5)\end{array}$ & $\begin{array}{c}23.1 \\
(16.6-31.1)\end{array}$ & $\begin{array}{c}88.5 \\
(73.5-95.5)\end{array}$ & $\begin{array}{c}76.6 \\
(59.5-88.0)\end{array}$ & $\begin{array}{c}63.7 \\
(42.3-80.8)\end{array}$ \\
\hline Recife & $\begin{array}{c}61.0 \\
(53.6-68.0)\end{array}$ & $\begin{array}{c}21.8 \\
(15.5-29.7)\end{array}$ & $\begin{array}{c}84.7 \\
(70.6-92.7)\end{array}$ & $\begin{array}{c}34.5 \\
(26.8-43.0)\end{array}$ & $\begin{array}{c}84.7 \\
(70.6-92.7)\end{array}$ & $\begin{array}{c}67.0 \\
(52.5-78.9)\end{array}$ & $\begin{array}{c}46.1 \\
(31.0-61.9)\end{array}$ \\
\hline Salvador & $\begin{array}{c}83.8 \\
(78.5-88.0)\end{array}$ & $\begin{array}{c}19.4 \\
(14.1-26.0)\end{array}$ & $\begin{array}{c}61.1 \\
(49.1-71.9)\end{array}$ & $\begin{array}{c}32.1 \\
(26.3-38.5)\end{array}$ & $\begin{array}{c}61.1 \\
(49.1-71.9)\end{array}$ & $\begin{array}{c}35.2 \\
(24.4-47.7)\end{array}$ & $\begin{array}{c}28.0 \\
(14.7-46.8)\end{array}$ \\
\hline $\begin{array}{l}\text { Belo } \\
\text { Horizonte }\end{array}$ & $\begin{array}{c}74.7 \\
(67.4-80.7)\end{array}$ & $\begin{array}{c}42.7 \\
(33.6-52.2)\end{array}$ & $\begin{array}{c}89.5 \\
(56.8-98.2)\end{array}$ & $\begin{array}{c}22.9 \\
(15.1-33.1)\end{array}$ & $\begin{array}{c}89.5 \\
(56.8-98.2)\end{array}$ & $\begin{array}{c}60.7 \\
(39.5-78.5)\end{array}$ & $\begin{array}{c}83.9 \\
(64.3-93.7)\end{array}$ \\
\hline $\begin{array}{l}\text { City of } \\
\text { Rio de } \\
\text { Janeiro }\end{array}$ & $\begin{array}{c}64.4 \\
(57.2-71.0)\end{array}$ & $\begin{array}{c}26.9 \\
(20.4-34.6)\end{array}$ & $\begin{array}{c}86.1 \\
(73.8-93.1)\end{array}$ & $\begin{array}{c}31.0 \\
(23.6-39.5)\end{array}$ & $\begin{array}{c}86.1 \\
(73.8-93.1)\end{array}$ & $\begin{array}{c}63.1 \\
(48.0-76.1)\end{array}$ & $\begin{array}{c}64.5 \\
(47.9-78.3)\end{array}$ \\
\hline $\begin{array}{l}\text { City of } \\
\text { São } \\
\text { Paulo }\end{array}$ & $\begin{array}{c}59.5 \\
(52.0-66.7)\end{array}$ & $\begin{array}{c}23.3 \\
(16.1-32.5)\end{array}$ & $\begin{array}{c}91.6 \\
(72.9-97.8)\end{array}$ & $\begin{array}{c}23.2 \\
(15.9-32.5)\end{array}$ & $\begin{array}{c}91.6 \\
(72.9-97.8)\end{array}$ & $\begin{array}{c}77.2 \\
(56.4-89.9)\end{array}$ & $\begin{array}{c}61.2 \\
(39.3-79.4)\end{array}$ \\
\hline Curitiba & $\begin{array}{c}59.7 \\
(51.7-67.2)\end{array}$ & $\begin{array}{c}31.2 \\
(23.1-40.6)\end{array}$ & $\begin{array}{c}99.0 \\
(93.7-99.9)\end{array}$ & $\begin{array}{c}31.2 \\
(22.3-41.9)\end{array}$ & $\begin{array}{c}99.0 \\
(93.7-99.9)\end{array}$ & $\begin{array}{c}68.4 \\
(46.3-84.5)\end{array}$ & $\begin{array}{c}73.3 \\
(46.6-89.6)\end{array}$ \\
\hline $\begin{array}{l}\text { Porto } \\
\text { Alegre }\end{array}$ & $\begin{array}{c}77.4 \\
(70.9-82.8)\end{array}$ & $\begin{array}{c}35.9 \\
(28.3-44.3)\end{array}$ & $\begin{array}{c}98.9 \\
(94.3-99.8)\end{array}$ & $\begin{array}{c}33.9 \\
(26.6-42.0)\end{array}$ & $\begin{array}{c}98.9 \\
(94.3-99.8)\end{array}$ & $\begin{array}{c}80.6 \\
(64.0-90.6)\end{array}$ & $\begin{array}{c}63.6 \\
(46.1-78.0)\end{array}$ \\
\hline $\begin{array}{l}\text { Campo } \\
\text { Grande }\end{array}$ & $\begin{array}{c}77.6 \\
(71.2-82.9)\end{array}$ & $\begin{array}{c}52.8 \\
(45.7-59.8)\end{array}$ & $\begin{array}{c}94.7 \\
(76.9-99.0)\end{array}$ & $\begin{array}{c}13.7 \\
(9.8-18.7)\end{array}$ & $\begin{array}{c}94.7 \\
(76.9-99.0)\end{array}$ & $\begin{array}{c}69.3 \\
(53.8-81.4)\end{array}$ & $\begin{array}{c}65.5 \\
(47.6-79.8)\end{array}$ \\
\hline Brasília & $\begin{array}{c}75.9 \\
(70.3-80.8)\end{array}$ & $\begin{array}{c}30.5 \\
(24.3-37.5)\end{array}$ & $\begin{array}{c}88.5 \\
(68.6-96.4)\end{array}$ & $\begin{array}{c}18.8 \\
(13.7-25.2)\end{array}$ & $\begin{array}{c}88.5 \\
(68.6-96.4)\end{array}$ & $\begin{array}{c}58.9 \\
(40.3-75.2)\end{array}$ & $\begin{array}{c}57.8 \\
(51.2-64.1)\end{array}$ \\
\hline Total & $\begin{array}{c}67.0 \\
(65.0-68.9)\end{array}$ & $\begin{array}{c}28.9 \\
(26.8-31.2)\end{array}$ & $\begin{array}{c}85.8 \\
(82.1-88.8)\end{array}$ & $\begin{array}{c}28.1 \\
(25.9-30.4)\end{array}$ & $\begin{array}{c}85.8 \\
(82.1-88.8)\end{array}$ & $\begin{array}{c}63.9 \\
(59.1-68.5)\end{array}$ & $\begin{array}{c}59.3 \\
(53.6-64.8)\end{array}$ \\
\hline $\begin{array}{l}p \text {-value } \\
\chi^{2}\end{array}$ & $<0.001$ & & $<0.001$ & & $<0.001$ & 0.001 & 0.011 \\
\hline
\end{tabular}


Table 5. Proportional distribution and confidence intervals $(95 \% \mathrm{Cl})$ of self-rated health, $\mathrm{PHQ}-2$ score, usual source of care, and discrimination in female sex workers according to the study city. Brazil, 2016.

\begin{tabular}{|c|c|c|c|c|c|c|c|}
\hline \multirow{3}{*}{ City } & \multicolumn{3}{|c|}{ Health self-assessment } & \multirow{2}{*}{$\begin{array}{c}\text { PHQ-2 } \\
\\
\text { Positive }\end{array}$} & \multirow[b]{2}{*}{$\begin{array}{l}\text { SUS as } \\
\text { a usual } \\
\text { source of } \\
\text { care }\end{array}$} & \multicolumn{2}{|c|}{ Health service discrimination } \\
\hline & $\begin{array}{l}\text { Very } \\
\text { good/ } \\
\text { good }\end{array}$ & Fair & $\begin{array}{c}\text { Bad/very } \\
\text { bad }\end{array}$ & & & $\begin{array}{c}\text { Discrimination } \\
\text { for being a } \\
\text { FSP }\end{array}$ & $\begin{array}{c}\text { Stating } \\
\text { oneself as a } \\
\text { FSP in health } \\
\text { services }\end{array}$ \\
\hline & $\%(95 \% \mathrm{Cl})$ & $\%(95 \% \mathrm{Cl})$ & $\%(95 \% \mathrm{Cl})$ & $\%(95 \% \mathrm{Cl})$ & $\%(95 \% \mathrm{Cl})$ & $\%(95 \% \mathrm{Cl})$ & $\%(95 \% \mathrm{Cl})$ \\
\hline Manaus & $\begin{array}{c}66.7 \\
(61.5-71.6)\end{array}$ & $\begin{array}{c}30.8 \\
(26.0-36.0)\end{array}$ & $\begin{array}{c}2.5 \\
(1.2-5.1)\end{array}$ & $\begin{array}{c}11.0 \\
(7.7-15.5)\end{array}$ & $\begin{array}{c}96.9 \\
(92.8-98.7)\end{array}$ & $9.1(6.1-13.2)$ & $\begin{array}{c}21.9 \\
(17.7-26.8)\end{array}$ \\
\hline Belém & $\begin{array}{c}67.2 \\
(60.7-73.0)\end{array}$ & $\begin{array}{c}29.7 \\
(24.3-35.8)\end{array}$ & $\begin{array}{c}3.1 \\
(1.7-5.5)\end{array}$ & $\begin{array}{c}21.9 \\
(17.3-27.2)\end{array}$ & $\begin{array}{c}93.3 \\
(88.8-96.1)\end{array}$ & $\begin{array}{c}16.5 \\
(12.3-21.8)\end{array}$ & $\begin{array}{c}29.6 \\
(24.5-35.3)\end{array}$ \\
\hline Fortaleza & $\begin{array}{c}63.4 \\
(56.2-70.0)\end{array}$ & $\begin{array}{c}32.4 \\
(26.0-39.6)\end{array}$ & $\begin{array}{c}4.2 \\
(2.4-7.2)\end{array}$ & $\begin{array}{c}15.8 \\
(11.2-21.7)\end{array}$ & $\begin{array}{c}92.3 \\
(87.2-95.4)\end{array}$ & $\begin{array}{c}29.6 \\
(23.6-36.4)\end{array}$ & $\begin{array}{c}29.9 \\
(23.9-36.6)\end{array}$ \\
\hline Recife & $\begin{array}{c}60.6 \\
(54.1-66.7)\end{array}$ & $\begin{array}{c}33.4 \\
(27.8-39.4)\end{array}$ & $\begin{array}{c}6.1 \\
(3.4-10.7)\end{array}$ & $\begin{array}{c}30.1 \\
(24.1-36.8)\end{array}$ & $\begin{array}{c}97.8 \\
(93.8-99.2)\end{array}$ & $\begin{array}{c}13.5 \\
(9.3-19.3)\end{array}$ & $\begin{array}{c}42.5 \\
(35.9-49.4)\end{array}$ \\
\hline Salvador & $\begin{array}{c}50.6 \\
(44.0-57.0)\end{array}$ & $\begin{array}{c}40.7 \\
(34.2-47.6)\end{array}$ & $\begin{array}{c}8.7 \\
(5.4-13.9)\end{array}$ & $\begin{array}{c}28.6 \\
(22.4-35.7)\end{array}$ & $\begin{array}{c}88.8 \\
(81.2-93.6)\end{array}$ & $\begin{array}{c}17.2 \\
(12.7-22.7)\end{array}$ & $\begin{array}{c}23.4 \\
(18.1-29.6)\end{array}$ \\
\hline $\begin{array}{l}\text { Belo } \\
\text { Horizonte }\end{array}$ & $\begin{array}{c}84.5 \\
(78.2-89.2)\end{array}$ & $\begin{array}{c}12.9 \\
(8.9-18.4)\end{array}$ & $\begin{array}{c}2.6 \\
(0.8-8.1)\end{array}$ & $\begin{array}{c}28.1 \\
(21.3-36.2)\end{array}$ & $\begin{array}{c}76.2 \\
(67.0-83.5)\end{array}$ & $\begin{array}{c}28.3 \\
(22.1-35.4)\end{array}$ & $\begin{array}{c}16.8 \\
(12.5-22.2)\end{array}$ \\
\hline $\begin{array}{l}\text { City of } \\
\text { Rio de } \\
\text { Janeiro }\end{array}$ & $\begin{array}{c}60.5 \\
(54.1-66.5)\end{array}$ & $\begin{array}{c}34.8 \\
(29.2-40.8)\end{array}$ & $\begin{array}{c}4.7 \\
(2.7-8.2)\end{array}$ & $\begin{array}{c}35.9 \\
(30.4-41.9)\end{array}$ & $\begin{array}{c}97.1 \\
(95.0-98.4)\end{array}$ & $\begin{array}{c}18.9 \\
(14.7-24.1)\end{array}$ & $\begin{array}{c}33.8 \\
(27.9-40.2)\end{array}$ \\
\hline $\begin{array}{l}\text { City of } \\
\text { São } \\
\text { Paulo }\end{array}$ & $\begin{array}{c}58.4 \\
(50.9-65.5)\end{array}$ & $\begin{array}{c}36.3 \\
(29.3-44.0)\end{array}$ & $\begin{array}{c}5.3 \\
(2.9-9.4)\end{array}$ & $\begin{array}{c}32.3 \\
(25.9-39.4)\end{array}$ & $\begin{array}{c}94.8 \\
(90.4-97.3)\end{array}$ & $\begin{array}{c}15.6 \\
(11.0-21.5)\end{array}$ & $\begin{array}{c}26.1 \\
(20.3-32.7)\end{array}$ \\
\hline Curitiba & $\begin{array}{c}64.5 \\
(56.8-71.5)\end{array}$ & $\begin{array}{c}29.7 \\
(23.2-37.2)\end{array}$ & $\begin{array}{c}5.8 \\
(3.0-10.9)\end{array}$ & $\begin{array}{c}26.8 \\
(20.5-34.2)\end{array}$ & $\begin{array}{c}90.9 \\
(84.3-94.9)\end{array}$ & $\begin{array}{c}19.1 \\
(13.8-25.7)\end{array}$ & $\begin{array}{c}15.7 \\
(10.7-22.5)\end{array}$ \\
\hline $\begin{array}{l}\text { Porto } \\
\text { Alegre }\end{array}$ & $\begin{array}{c}77.7 \\
(71.0-83.2)\end{array}$ & $\begin{array}{c}17.9 \\
(13.4-23.6)\end{array}$ & $\begin{array}{c}4.4 \\
(1.9-9.8)\end{array}$ & $\begin{array}{c}22.8 \\
(17.7-28.9)\end{array}$ & $\begin{array}{c}90.1 \\
(84.2-94.0)\end{array}$ & $\begin{array}{c}27.0 \\
(21.3-33.7)\end{array}$ & $\begin{array}{c}23.3 \\
(18.7-28.8)\end{array}$ \\
\hline $\begin{array}{l}\text { Campo } \\
\text { Grande }\end{array}$ & $\begin{array}{c}67.1 \\
(61.0-72.6)\end{array}$ & $\begin{array}{c}30.8 \\
(25.3-36.9)\end{array}$ & $\begin{array}{c}2.1 \\
(1.0-4.6)\end{array}$ & $\begin{array}{c}46.6 \\
(40.7-52.5)\end{array}$ & $\begin{array}{c}71.9 \\
(63.9-78.7)\end{array}$ & $\begin{array}{c}36.4 \\
(30.6-42.6)\end{array}$ & $\begin{array}{c}14.4 \\
(10.4-19.7)\end{array}$ \\
\hline Brasília & $\begin{array}{c}69.2 \\
(63.2-74.7)\end{array}$ & $\begin{array}{c}28.1 \\
(22.6-34.3)\end{array}$ & $\begin{array}{c}2.6 \\
(1.3-5.4)\end{array}$ & $\begin{array}{c}30.4 \\
(24.4-37.1)\end{array}$ & $\begin{array}{c}87.9 \\
(82.2-92.0)\end{array}$ & $\begin{array}{c}25.4 \\
(20.3-31.3)\end{array}$ & $\begin{array}{c}11.9 \\
(8.6-16.2)\end{array}$ \\
\hline Total & $\begin{array}{c}65.8 \\
(63.9-67.6)\end{array}$ & $\begin{array}{c}29.9 \\
(28.2-31.7)\end{array}$ & $\begin{array}{c}4.3 \\
(3.6-5.2)\end{array}$ & $\begin{array}{c}27.7 \\
(26.0-29.5)\end{array}$ & $\begin{array}{c}90.2 \\
(88.7-91.5)\end{array}$ & $\begin{array}{c}21.3 \\
(19.8-23.0)\end{array}$ & $\begin{array}{c}24.3 \\
(22.7-25.9)\end{array}$ \\
\hline $\begin{array}{l}p \text {-value } \\
\chi^{2}\end{array}$ & $<0.001$ & $<0.001$ & $<0.001$ & $<0.001$ & $<0.001$ & $<0.001$ & $<0.001$ \\
\hline
\end{tabular}




\section{DISCUSSION}

In this article, we present indicators related to sexual and reproductive health and health status of female sex workers in 12 Brazilian cities. These indicators showed important variations between cities, with emphasis on the coverage of Pap smears, HIV and syphilis tests, and antenatal indicators, which showed a variation equal to or greater than 20 percentage points.

The limitations of this study refer to the RDS method used to recruit FSW. Admittedly, one of the factors influencing the development of networks is the homophily effect, defined as the participants' tendency to recruit peers with characteristics similar to theirs ${ }^{20}$. The payment of incentives also influences the formation of the network, encouraging the participation of people with lower income and more socially marginalized ${ }^{21}$. The study field can also affect the network composition, according to the characteristics of the FSW that work in the vicinity ${ }^{22}$. Thus, the samples obtained in each city, of pre-established size, may not reach the diversity of characteristics of all FSW subgroups in the city. This may have influenced the worst health indicators found in cities like Salvador, where the sample was composed of the most vulnerable sex workers, crack users, with low education and monthly income, and the best indicators recorded in cities such as Belo Horizonte, in which the participants had higher education and monthly income, and a low percentage of illicit drug use ${ }^{13}$.

In the evaluation of sexual and reproductive health indicators, it was found that, in all cities, the coverage of Pap smears among FSW, in the last three years, was lower than the estimate of the Brazilian female population ${ }^{23}$ and followed the national profile, with less coverage in the North and Northeast regions and greater in the South and Southeast ${ }^{24}$.

The proportion of FSW who had been tested for HIV was higher than that found in the biological and behavioral survey, carried out in 2016 with men who have sex with men $(\mathrm{MSM})^{25}$. The greater coverage of HIV testing among them is probably explained in antenatal care. This hypothesis is reinforced by observing that the cities with the greatest coverage of HIV tests, Campo Grande and Porto Alegre, have high antenatal coverage, above $90 \%{ }^{26}$.

In all municipalities, the proportion of FSW who have been tested for syphilis in the year preceding the survey was much lower than the coverage of testing for syphilis during antenatal care in women in the Brazilian population, which was $89.1 \%{ }^{27}$. It is important to highlight that, in all cities, the frequency of testing for syphilis among sex workers was lower than that of testing for HIV. This represents an important gap in the provision of integrated STI prevention services ${ }^{15}$.

An important reason for not taking the HIV test was "being afraid or ashamed", showing stigma and discrimination as barriers to the diagnosis of HIV ${ }^{28}$. Furthermore, Curitiba and Brasilia, with higher proportions of not taking the HIV test for fear or shame, were also cities with lower frequencies of women who reveal themselves to be sex workers to health care providers.

It is noteworthy that the proportion of FSW who use condom in all vaginal and anal intercourses with a steady partner was low, at 34.8 and $38.9 \%$, respectively, suggesting a more 
trusting relationship with these partners, and with clients, much higher, at 80.5 and $81.1 \%$, respectively, which indicates more concern with the prevention of STI with these partners.

The proportion of FSW who use some contraceptive method is lower than that of the Brazilian population by 13 percentage points. The differences found between the type of contraception used by them follow the profile of the population of Brazilian women: while those in the North region are more sterilized and the male condom is the most used contraceptive method, those in the South and Southeast regions use oral contraceptives ${ }^{29}$.

When investigating the antenatal coverage profile, with the exception of Curitiba and Porto Alegre, the proportion of FSW who had antenatal care in each city was lower than that found in the Brazilian population of women (97.9\%). Regarding the differences between cities, there is a well-known pattern of regional inequalities in the country, with the lowest coverage of antenatal care in the North and Northeast regions ${ }^{30}$. The indicators of beginning antenatal care in the first trimester and having seven or more antenatal consultations also showed lower proportions than among women in the Brazilian population ${ }^{30,31}$.

It is noted that the worst self-assessment of health was found in Salvador, where the network is composed of highly vulnerable FSW, reinforcing that incomplete education and unfavorable socioeconomic conditions are determinants of worse self-assessment of health ${ }^{32}$.

With regard to the proportion of FSW with a positive score for major depressive disorder on the PHQ-2 scale, there is also a high proportion in Salvador, where these women are more vulnerable. However, the highest proportion of FSW with a positive score for depressive episodes was registered in Campo Grande, with the highest proportion of sex workers who felt discriminated by their occupation $(36.4 \%)$ and the highest proportion of those who frequently use alcohol ${ }^{13}$. This reinforces the multifaceted aspect of depression in FSW, which, in addition to precarious socioeconomic conditions, has stigma, the use of alcohol and drugs and HIV infection as strongly associated factors ${ }^{33,34}$.

The feeling of discrimination influences women not to reveal their occupation as sex worker in health care. In a previous work, with data from the same survey, the lack of disclosure of occupation as sex worker in health services was significantly associated with not having an HIV test in the last 12 months $^{10}$.

Given the high proportion of FSW who use the SUS as a usual source of care in all cities, these results reinforce the need to implement local policies to fight the stigma and discrimination of these women in order to ensure the appropriate adoption of preventive actions in public health services.

The results presented in this work are of great relevance for the planning of health policies aimed at sex workers at both the municipal and national levels. The results not only reinforce the condition of greater vulnerability of the FSW, but also reveal the differences found between the regions, which accompany the inequalities of the health indicators of the Brazilian population of women ${ }^{29,35}$.

Additionally, the results show that there is still a large gap for scaling up frequent HIV and syphilis testing in all municipalities. In this sense, it is essential to consider barriers to 
accessing health, such as stigma and discrimination, which hinder the specific needs of FSW from being addressed.

\section{ACKNOWLEDGMENTS}

We thank the female sex workers participating in the study and the local teams who carried out the fieldwork in the 12 cities. We also thank the Ministry of Health and the Department of Chronic Conditions and Sexually Transmitted Infections (Departamento de Condições Crônicas e Infecções Sexualmente Transmissiveis - DCCI) for funding and support from The Brazilian FSW Group.

\section{REFERENCES}

1. Zalla LC, Herce ME, Edwards JK, Michel J, Weir SS. The burden of HIV among female sex workers, men who have sex with men and transgender women in Haiti: results from the 2016 Priorities for Local AIDS Control Efforts (PLACE) study. J Int AIDS Soc 2019; 22 (7): e25281. https: / / doi.org/10.1002/jia2.25281

2. Lima FSS, Merchán-Hamann E, Urdaneta M, Damacena GN, Szwarcwald CL. Fatores associados à violência contra mulheres profissionais do sexo de dez cidades brasileiras. Cad Saúde Pública 2017; 33 (2): e00157815. https: / doi.org/10.1590/0102-311x00157815

3. Shannon K, Strathdee SA, Goldenberg SM, Duff P, Mwangi P, Rusakova M, et al. Global epidemiology of HIV among female sex workers: influence of structural determinants. Lancet 2015; 385 (9962): 55-71. https: / / doi.org/10.1016/S0140-6736(14)60931-4

4. Âdo RA, Young PW, Horth RZ, Inguane C, Sathane I, Ngale K, et al. High Burden of HIV Infection and Risk Behaviors Among Female Sex Workers in Three Main Urban Areas of Mozambique. AIDS Behav 2016; 20 (4): 799-810. https: / / doi.org/10.1007/s10461-015-1140-9

5. Brasil. Ministério da Saúde. Departamento de DST/ AIDS e Hepatites Virais. Pesquisa de Conhecimentos, Atitudes e Práticas na População Brasileira. Brasília: Ministério da Saúde; 2013.

6. Damacena GN, Szwarcwald CL, Souza Junior PR, Dourado I. Risk factors associated with HIV prevalence among female sex workers in 10 Brazilian cities. J Acquir Immune Defic Syndr 2011; 57 (3): S144-52. https: / / doi.org/10.1097/QAI.0b013e31821e9bf6
7. World Health Organization, UNDP/UNFPA/UNICEF/ WHO/World Bank. Sexual health and its linkages to reproductive health: an operational approach. Genebra: World Health Organization; 2017.

8. Brasil. Ministério da Saúde. Secretaria de Atenção à Saúde. Departamento de Ações Programáticas Estratégicas. Política nacional de atenção integral à saúde da mulher: princípios e diretrizes. Brasília: Ministério da Saúde; 2004.

9. Brasil. Ministério da Saúde. Secretaria de Atenção à Saúde. Departamento de Atenção Básica. Saúde sexual e saúde reprodutiva. Cadernos de Atenção Básica 2013. Brasília: Ministério da Saúde; 2013.

10. Dourado I, Guimaraes MDC, Damacena GN, Magno L, Souza Junior PRB, Szwarcwald CL. Sex work stigma and non-disclosure to health care providers: data from a large RDS study among FSW in Brazil. BMC Int Health Hum Rights 2019; 19 (1): 8. https: / doi. org/10.1186/s12914-019-0193-7

11. Ferreira Júnior OC, Franchini M, Bazzo ML, Motta LR, Veras NMC, Werson ESS. Manual Técnico para o diagnóstico da infecção pelo HIV. Brasília: Ministério da Saúde; 2014.

12. Damacena GN, Szwarcwald CL, de Souza Júnior PR, Ferreira Júnior OC, Almeida WS, Pascom ARP, et al. Application of the respondent-driven sampling methodology in a biological and behavioral surveillance survey among female sex workers, Brazil, 2016. Rev Bras Epidemiol 2019; 22 (Suppl 1): e190002. http:/ / doi.org/10.1590/1980-549720190002.supl.1 
13. Braga, LP, Szwarcwald, CL, Damacena, GN. Caracterização de mulheres trabalhadoras do sexo em capitais brasileiras, 2016. Epidemiol Serv Saúde 2020; 29 (4): e2020111. http:/ / doi.org/10.5123/ s1679-49742020000400002

14. Instituto Nacional de Câncer José Alencar Gomes da Silva. Diretrizes brasileiras para o rastreamento do câncer do colo do útero. $2^{\text {a }}$ edição revista, ampliada e atualizada [internet]. Rio de Janeiro: INCA; 2016.

15. World Health Organization. Consolidated guidelines on HIV prevention, diagnosis, treatment and care for key populations - 2016 update. Genebra: World Health Organization; 2016.

16. Brasil. Ministério da Saúde. Secretaria de Atenção à Saúde. Atenção ao pré-natal de baixo risco. Cadernos de Atenção Básica. Brasília: Ministério da Saúde. Secretaria de Atenção à Saúde; 2013.

17. Kroenke K, Spitzer RL, Williams JB. The Patient Health Questionnaire-2: validity of a two-item depression screener. Med Care 2003; 41 (11): 1284-92. http:// doi.org/10.1097/01.MLR.0000093487.78664.3C

18. Szwarcwald CL, Souza Junior PRB, Damacena GN, Barbosa Junior AB, Kendall C. Analysis of data collected by RDS among sex workers in 10 Brazilian cities, 2009: estimation of the prevalence of HIV, variance, and design effect. J Acquir Immune Defic Syndr 2011; 57 (3): S129-35. https: / / doi.org/ 10.1097/ QAI.0b013e31821e9a36

19. Salganik MJ, Heckathorn DD. Sampling and estimation in hidden populations using respondent-driven sampling. Sociological Methodology 2004; 34 (1): 193240. https: / / doi.org/10.1111/j.0081-1750.2004.00152.x

20. Barbosa Júnior A, Pascom ARP, Szwarcwald CL, Kendall C, McFarland W. Transfer of sampling methods for studies on most-at-risk populations (MARPs) in Brazil. Cad Saude Publica 2011; 27(Suppl 1): s36-44. https: / / doi.org/10.1590/S0102-311X2011001300005

21. McCreesh N, Frost SD, Seeley J, Katongole J, Tarsh $\mathrm{MN}$, Ndunguse R, et al. Evaluation of respondentdriven sampling. Epidemiology 2012; 23 (1): 138-47. https: / doi.org/10.1097/EDE.0b013e31823ac17c

22. Damacena GN, Szwarcwald CL, Souza Júnior PRB. HIV risk practices by female sex workers according to workplace. Rev Saúde Pública 2014; 48: 428-37. https:// doi.org/10.1590/s0034-8910.2014048004992

23. Oliveira MM, Andrade SSCA, Oliveira PPV, Silva GA, Silva MMA, Malta DC. Cobertura de exame Papanicolaou em mulheres de 25 a 64 anos, segundo a Pesquisa Nacional de Saúde e o Sistema de Vigilância de Fatores de Risco e Proteção para Doenças Crônicas por Inquérito Telefônico, 2013. Rev Bras Epidemiol 2018; 21 : e180014. https: / / doi.org/10.1590/1980-549720180014
24. Magalhães RLB, Borges BVS, Oliveira VMC, Brito GMI, Resende AKA, Gir E. Fatores associados à realização do exame citopatológico em mulheres profissionais do sexo. Revista Baiana Enferm 2018; 32. http: / / doi. org/10.18471/rbe.v32.25931

25. Guimaraes MDC, Kendall C, Magno L, Rocha GM, Knauth DR, Leal AF, et al. Comparing HIV risk-related behaviors between 2 RDS national samples of MSM in Brazil, 2009 and 2016. Medicine (Baltimore) 2018; 97 (1S Suppl 1): S62-8. https: / / doi.org/10.1097/ MD.0000000000009079

26. Brito AM, Szwarcwald CL, Damacena GN, Dourado IC. HIV testing coverage among female sex workers, Brazil, 2016. Rev Bras Epidemiol 2019; 22 (Suppl 1): e190006. http:/ / doi.org/10.1590/1980-549720190006.supl.1

27. Domingues RMSM, Szwarcwald CL, Souza Júnior PRB, Leal MC. Prevalence of syphilis in pregnancy and prenatal syphilis testing in Brazil: birth in Brazil study. Rev Saude Publica 2014; 48 (5): 766-74. https: / / doi.org/10.1590/S0034-8910.2014048005114

28. Martins TA, Kerr L, Macena RHM, Mota RS, Dourado I, Brito AM, et al. Incentives and barriers to HIV testing among female sex workers in Ceará. Rev Saude Publica 2018; 52: 64. https: / / doi.org/10.11606/ s1518-8787.2018052000300

29. Trindade RE, Siqueira BB, Paula TF, FelisbinoMendes MS. Uso de contracepção e desigualidades do planejamento reprodutivo das mulheres brasileiras. Cien Saude Col 2019 [cited on March 8, 2020]; 0298. Available at: https: / / www.cienciaesaudecoletiva.com.br/artigos/ uso-de-contracepcao-e-desigualdades-do-planejamentoreprodutivo-das-mulheres-brasileiras / 17372

30. Leal MC, Esteves-Pereira AP, Viellas EF, Domingues RMSM, Gama SGN. Prenatal care in the Brazilian public health services. Rev Saude Publica 2020; 54: 8. https: / doi.org/10.11606/s1518-8787.2020054001458

31. Nunes ADS, Amador AE, Dantas APQM, Azevedo UN, Barbosa IR. Acesso à assistência pré-natal no Brasil: análise dos dados da Pesquisa Nacional de Saúde. RBPS 2017; 30 (3): 1-10. https: / / doi.org/10.5020/18061230.2017.6158

32. Chandola T, Jenkinson C. Validating self-rated health in different ethnic groups. Ethn Health 2000; 5 (2): 151-9. https: / / doi.org/10.1080/ 713667451

33. Rael CT, Davis A. Depression and key associated factors in female sex workers and women living with HIV/AIDS in the Dominican Republic. Int J STD AIDS 2017; 28 (5): 433-40. https: / / doi.org/10.1177/0956462416651374

34. Beattie, TS, Smilenova B, Krishnaratne S, Mazzuca, A. Mental health problems among female sex workers in low- and middle-income countries: A systematic review and meta-analysis. PLoS Med 2020; 17 (9): e1003297. https: / / doi.org/10.1371/journal.pmed.1003297 
35. Silva ICM, Restrepo-Mendez MC, Costa JC, Ewerling F, Hellwig F, Ferreira LZ, et al. Mensuração de desigualdades sociais em saúde: conceitos e abordagens metodológicas no contexto brasileiro. Epidemiol Ser Saúde 2018; 27 (1): e000100017. https: / / doi. org/10.5123/s1679-49742018000100017

Received on: 03/25/2021

Revised on: 07/15/2021

Accepted on: 07/27/2021
Authors' contributions: LPB: Conceptualization, Data curation, Formal analysis, Writing - first writing, Writing - proofreading and editing. GND: Conceptualization, Data curation, Formal analysis, Writing - first writing, Writing - proofreading and editing. CLS: Conceptualization, Data curation, Formal analysis, Writing - first writing, Writing proofreading and editing. MDCG: Conceptualization, Data curation, Formal analysis, Writing - first writing, Writing - proofreading and editing. 